\title{
Determinants Of Capital Market Development In Ghana
}

\author{
Emmanuel Acquah-Sam \\ Wisconsin International University College, North-Legon, Ghana
}

doi: 10.19044/esj.2016.v12n1p251 URL:http://dx.doi.org/10.19044/esj.2016.v12n1p251

\begin{abstract}
This study sought to investigate the macroeconomic factors that influence capital market development in Ghana. The study was based on multiple linear regression analysis based on quarterly secondary data spanning from 1991 to 2011. Exploratory data analysis was used to verify and resolve basic assumptions of multivariate analysis. Research tools such as Principal Component Analysis (PCA), Structural Equation Modelling (SEM) through Path Analysis (i.e. Layered Regression technique) and tests of interactions among variables were used to test for the linear relationships between key variables in the estimated equations. The main empirical contribution of this study is that capital market development in Ghana is positively influenced by gross capital formation (GFI) and GDP growth, but negatively influenced by Treasury bill rates (T-BILLS). Inflation and foreign direct investments (FDI) did not prove significant in the estimated equation. These imply that policy-makers in Ghana should promote the growth of real income or output, and physical infrastructural development to enhance capital market development in Ghana. Interest rates and the government of Ghana's Treasury bill rates must be fixed at reasonable levels to encourage investments in capital market securities. The application of this study is that the results and the estimated model are useful for predicting long run growth paths of capital markets in developing countries when country specific problems are well addressed.
\end{abstract}

Keywords: Ghana, stock market development, economic growth, multiple linear regression, Structural equation modelling

\section{Introduction}

Capital market development has become the focus of governments, policy-makers, market regulators and operators for the mobilisation of long term capital for businesses and governments' profitable investments to promote pro-poor economic growth in developing nations. The World Bank 
(2009; cited in World Bank Institute, 2013) reported that in 2008, private investment flows to developing countries declined by more than 40 percent, as access to international debt markets dried up and inflows of portfolio equity all but ceased. In 2013, Ghana's Minister for Finance and Economic Planning was reported to have said that the economy of Ghana was still facing challenges, with both revenue receipts and expenditure falling below their targets due to economic slowdown and a fall in global commodity prices (Ablordeppey, 2013). Again, in 2013, Ministers of African countries expressed the need for African countries to maintain solid and inclusive propoor economic growth and acknowledged that this is possible only if sufficient investment funds could be harnessed to address the challenges in infrastructure, energy, poverty, and unemployment. Inadequate infrastructure hinders economic growth everywhere on the continent of Africa by at least $2 \%$ each year, and reduces the productivity of the private sector by about $40 \%$. This is equal to about forty (40) billion dollars loss in gross domestic product (GDP) every year (Kaberuka, 2013). Cohn (2002) wrote that bank financing in Sub-Saharan Africa (SSA) has historically been associated with high interest rates charged on commercial loans. Rates vary from countries to countries, but interest rates in the range of $25 \%$ to $35 \%$ are quite common, and it is rare to see interest rates below $20 \%$. This has made it very difficult for most businesses to raise funds for business activities and has thus stifled economic growth As part of the solutions to the problems of lack of financial capital for pro-poor economic growth in developing nations, and most especially nations in Sub-Saharan Africa, capital markets have been established in most countries in Sub-Saharan African countries to enable governments and businesses raise relatively cheaper long-term capital for growth of business firms' and governments' economic activities to spur propoor economic growth and alleviate poverty (Odife, 2002). Evans (2010) reported that by the end of 2009, more than fifty (50) percent of the fifty-four (54) African countries had established capital markets.

The Ghana Stock Exchange (GSE) began operation in 1990. Ghana's market was adjudged the world's best performing market at the end of 2004 with a year return of $144 \%$ in US dollar terms compared with $30 \%$ return by Morgan Stanley Capital International Global Index (Databank Group, 2004). In 2010 the GSE could boast of sixteen (16) LDMS and thirty-four (34) listed companies with a market capitalisation of GH\$19,868 million (Evans, 2010). In 2013, the GSE - Composite Index (GSE-CI) recorded a year to date gain of $78.81 \%$ ending the year with $2,145.20$ point while the GSE Financial Stock Index (GSE-FSI) also recorded a return of $71.81 \%$ ending the year with 1,784.05 points. The return on index recorded on the Ghana Stock Exchange for the year 2013 made the Exchange one of the best performing stock markets in Sub-Saharan Africa. Domestic market 
capitalisation recorded a 76.68\% increase ending December 2014 with GH\$11,694.93 compared to GH\$6,753.14 recorded for the same period in 2012. By $3^{\text {rd }}$ December, 2015 the Exchange had forty-two (42) listed companies. As part of its development efforts the Ghana Fixed Income Market (GFIM) has been introduced to facilitate the secondary trading of all fixed income securities and other securities to be determined from time to time. In addition to this is the formation of the Ghana Alternative Market (GAX). The GAX accommodates' companies at various stages of their development, including start-ups and existing enterprises, both small and medium. Raising long term capital through GAX will be at a relatively lower cost to prospective companies which would access the market (GSE, 2013; 2015).

Despite the benefits offered by the sector, capital markets in developing nations and most especially the market in Ghana are bedevilled with a mirage of problems. Some works have been done on the relationship between capital market development and economic growth, and the determinants of stock market development in Ghana but little empirical works exists on the determinants of capital market development in Ghana. Most empirical studies have reported that the capital market in Ghana is still developing, illiquid, affected economic growth negatively, and at times insignificantly. Furthermore, it is lowly patronised by Ghanaian firms, low earnings by investors, strictly regulated, and has low media attention (Quartey \& Gaddah, 2007; Senbet \& Otchere, 2008; Agyeman, 2010; Mensah, Awunyo-Vitor, \& Sey, 2012; Owusu \& Odhiambo, 2013; Adusei, 2014; Osamwonyi \& Kasimu, 2013; Osei, 2004; Quaidoo, 2011; AcquahSam \& Salami, 2014; and Acquah-Sam, 2014). The current study was conducted to investigate the macroeconomic factors that will help the capital market in Ghana to develop to help address the problem of inadequate financial capital for pro-poor economic growth in Ghana. It is hoped that the findings of the study will help the managers of the economy, policy-makers, and market managers to propose policies or strategies and advice on ways to make the capital market impact positively on Ghana’s economic growth.

\section{Literature Review}

Levine $(1997 ; 2005)$ attested to the fact that countries with better developed financial systems experienced faster economic growth than those without it because a well-developed financial system ensures the flow of funds from surplus spending units to deficit spending units in society. Carlin \& Mayer (2003) found a strong relationship between the structure of financial systems operated by countries and economic growth. Thus, the rate of growth of an economy has a strong relationship with whether the economy is thriving on a bank-based financial system or a market-based financial 
system. Demirgüç-Kunt \& Levine (1996) concluded that banks, other financial intermediaries, and stock markets all grow and become more active and efficient as countries become richer. However, in higher income countries, stock markets become more active and efficient than banks. Goldsmith (1969), McKinnon (1973), and Shaw (1973) are among those who concluded that the capital market enhanced the mobilisation of domestic and foreign resources and facilitated investments.

UNITAR/DFM (2005) states that in recent years, the world and developing countries in particular have turned their attention to capital market development for two basic reasons: the collapse of the Soviet Union in the early 1990's; and the rapid growth of capital markets and their positive effect on developed nations of the world such as England and the USA. In most sub-Saharan African countries, the development of capital markets has been a deliberate national strategy to restructure their financial sectors and to privatise state owned enterprises that underperform so as to encourage greater economic growth and creation of wealth. Capital markets accelerate growth by facilitating the ability to trade ownership of firms, and allowing investors to hold diversified portfolios. Levine (1996) shows that countries that had more liquid stock markets in 1976 enjoyed both faster rates of capital accumulation and greater productivity gains over the next 18 years. Liquid capital markets enable investors to modify their portfolios quickly and cheaply. It facilitates investment projects and makes them less risky and, as a result, helps in facilitating capital formation, allocation, investment, and growth (Brasoveanu, Dragota, Catarama, \& Semenescu, 2008; Kolapo \& Adaramola, 2012, Garcia \& Liu, 1999). Acquah-Sam \& Salami (2014) concluded that capital market development has a positive and significant effect on long run economic growth in Ghana. They added that there was a positive bi-directional relationship between economic growth and capital market development, even though the stronger effect was from capital market development to economic growth.

The Calderon-Rossell Model considered economic growth and stock market liquidity as the main determinants of stock market development. The model used market capitalisation as a proxy for stock market development. The study established that stock market liquidity and economic growth are important determinants of stock market growth (Yartey, 2008). Garcia \& Liu (1999) reported on the determinants of capital market development. They used market capitalisation as a proxy for capital market development. They concluded that real income level, saving rate; financial intermediaries' development; and stock market liquidity are important predictors of stock market development, while macroeconomic stability does not prove significant. Finally, financial intermediaries and stock markets are complements instead of substitutes. Kemboi \& Tarus (2012) worked on 
macroeconomic determinants of stock market development in Kenya for the period 2000 to 2009, using quarterly secondary data. The results indicated that macroeconomic factors such as income level, banking sector development, and stock market liquidity were important determinants of the development of the Nairobi Stock market. The results also show that macroeconomic stability was not a significant predictor of the development of the securities market. Claessens, Klingebiel, \& Schmukler (2002) studied the determinants of the growing migration of stock market activity to international financial centres. It showed that FDI was positively correlated with stock market capitalisation and value traded. Quartey \& Gaddah (2007) looked at the long run determinants of stock market development in Ghana. The paper found that gross domestic savings, real income, domestic credit to the private sector, and exchange rate predicted the long run development of the GSE. However, Treasury bill rates had negative impact on the long run development of the GSE. Also, inflation did not prove to be a significant factor in predicting the long run development of the stock market. The World Bank (2013) defines Gross fixed capital formation (formerly gross domestic fixed investment) to include land improvements (fences, ditches, drains, and so on); plant, machinery, equipment purchases; construction of roads, railways, schools, offices, hospitals, private residential dwellings, and commercial and industrial buildings. Osaze (2007; cited in Ngerebo-A., \& Torbira, 2014)) theorised that these new issues contribute to the stock of capital in an economy and hence capital formation. Changes in interest rates have also been found to be inversely related to stocks. Fama (1981) argued that expected inflation is negatively correlated with anticipated real activity, which also positively relate to returns on the capital market. Therefore, capital market returns should be negatively correlated with expected interest rate.

Methodologically, the Calderon-Rossell Model (1991) was the first behavioural model that established economic growth and stock market liquidity as the main determinants of stock or capital market development. This model has been modified overtime to assess capital market determinants in some jurisdictions (Yartey, 2008; Quaidoo, 2011; Kemboi, \& Tarus, 2012). Market capitalisation was defined as follows:

$$
\mathrm{Y}=\mathrm{PV}
$$

Where;

$\mathrm{Y}=$ Market capitalization in local currency

$\mathrm{P}=$ the number of listed companies in the stock market

$\mathrm{V}=$ the local currency average price of listed companies

The model was formally presented as follows:

$$
\begin{aligned}
& \mathrm{Y}=\mathrm{PV}=\mathrm{Y}(\mathrm{G}, \mathrm{T}) \\
& \mathrm{V}=\mathrm{V}[\mathrm{G}, \mathrm{P}], \mathrm{P}=\mathrm{P}(\mathrm{T}, \mathrm{V})
\end{aligned}
$$


Where,

$\mathrm{G}=$ per capita GNP in local currency

$\mathrm{T}=$ turnover ratio

The structural equations are then expressed in the following reduced behavioural model:

$$
\begin{aligned}
& \log Y=\theta_{1} \log G+\theta_{2} \log T \\
& \log V=\alpha_{1} \log G+\alpha_{2} \log T \\
& \log P=\omega_{1} \log G+\omega_{2} \log T
\end{aligned}
$$

Finally,

$$
\log \mathrm{Y}=\left[\alpha_{1+} \omega_{1}\right] \log \mathrm{G}+\left[\alpha_{2+} \omega_{2}\right] \log \mathrm{T}
$$

Equation (7) above shows that stock market development is the combined effect of economic growth and liquidity on both stock prices and the number of listings.

The next section looks at methods used for analysis in this study and the theoretical and empirical underpinnings of factors that affect capital market development.

\section{Methodology}

The study is quantitative in nature. It made use of quarterly time series secondary data that spanned from 1991 to 2011. Data was collected from the Wold Bank Groups; Ghana Stock Exchange, Bank of Ghana, Data Bank Financial Services Ltd, and Ghana Statistical Services. The study used the modified version of the Calderon-Rossell model to test for the determinants of capital market development in Ghana (Yartey, 2008; Quaidoo, 2011; and Kemboi, \& Tarus, 2012)

The general multiple linear regression model for the study is given as:

$\mathrm{MKT}_{\mathrm{t}}=\mathrm{a}_{0}+\mathrm{a}_{1}$ GDP growth $+\mathrm{a}_{2} \mathrm{FDI}_{\mathrm{t}}+\mathrm{a}_{3} \mathrm{GFI}_{\mathrm{t}}+\mathrm{a}_{4} \mathrm{DFI}_{\mathrm{t}}+\mathrm{a}_{5} \mathrm{CML}_{\mathrm{t}}+$ $\mathrm{a}_{6} \mathrm{INF}_{\mathrm{t}}-\mathrm{a}_{7} \mathrm{~T}-\mathrm{BILLS}_{\mathrm{t}}+\mathrm{e}_{\mathrm{t}}$

Where, $\mathrm{a}_{0}$ is a constant. $\mathrm{a}_{1}, \mathrm{a}_{2}, \mathrm{a}_{3}, \mathrm{a}_{4}, \mathrm{a}_{5}, \mathrm{a}_{6}$, and $\mathrm{a}_{7}$ are the parameters or the coefficients of the variables under consideration. $t$ denotes time. The apriori expectations of the coefficients of the independent variables in the model are $\mathrm{a}_{0}, \mathrm{a}_{1}, \mathrm{a}_{2}, \mathrm{a}_{3}, \mathrm{a}_{4}, \mathrm{a}_{5} \mathrm{a}_{6}>0$, and $\mathrm{a}_{7}<0$. Market capitalisation (MKT) serves as the dependent variable. The independent variables in the model are GDP growth; gross capital formation (GFI), Development of financial intermediaries (DFI), Capital market liquidity (CML), foreign direct investment (FDI), macroeconomic stability (proxied by the rate of inflation), and interest rates (proxied by the 91-Day government Treasury bill rates).

Market capitalisation relative to GDP growth (MKT) is used as a proxy for capital market development (Garcia \& Liu, 1999). Yartey (2008). La Porta et al., (1996; cited in Kemboi, \& Tarus, 2012) wrote that as income increases, its cyclical component impacts the size of the capital market and 
its price index. In addition, because higher income usually goes hand in hand with better defined property rights, better education and better general environment for business, we expect it to have a positive effect on stock or capital market development. Garcia \& Liu (1999) and Ngerebo-A., \& Torbira (2014) revealed the existence of a positive and significant long run relationship between capital market activities and gross fixed capital formation. Development of financial intermediaries (DFI) is measured as the ratio of total credit to private sector to GDP. Kemboi, \& Tarus (2012), Nacuer et al., (2007), Garcia \& Liu (1999) and Yartey (2008) found support for a positive relationship between banking sector development and stock market development. Both the capital market and the banking sector intermediate savings towards investment projects, and they can be both complements and substitutes for capital mobilisation for economic growth (Demirguc-Kunt \& Levine, 1996). Capital market liquidity (CML) is proxied by stock turnover ratio, and value traded ratio. Yartey (2008) argued that liquid capital markets afford investors access to their savings, and thus boost their confidence in stock market investment. Adam \& Tweneboah (2009), and Claessens, et al. (2001) revealed the existence of a positive relationship between foreign direct investment (FDI) and stock market development. FDI is measured as foreign direct investment as a percentage of GDP. Consistent with previous studies, inflation has been used as a measure of macroeconomic stability (Nacuer et al., 2007; Garcia and Liu, 1999). Interest rate is proxied by the 91-Day government Treasury bill rates. Economic policy analysts are of the view that excess government spending leads ultimately to rising interest rates. Fama (1981) for example, argued that expected inflation is negatively correlated with anticipated real activity, which also positively relate to returns on the capital market. Therefore, capital market returns should be negatively correlated with expected interest rate.

Exploratory data analysis was used to ensure that the basic assumptions of regression were verified and resolved. Tools of analyses included Box-Cox mechanism (Li, 2005; Osborne, 2010), Durbin-Watson (Tsay, 1984); Principal Component Analysis (PCA); Structural Equation Modelling (SEM) through Path Analysis (i.e. Layered Regression technique); ANOVA, and test of interactions among independent variables. Four estimated equations were derived from the analysis, but we report on the factors that determine capital market development. The reasons for the choice of these methods are that they are multivariate techniques of analysis used to test hypotheses, linear relationships between key variables; eliminate variables with weak influences in estimated models or equations and to test for causal effects among variables (Cooper \& Schindler, 2011). Another area of concern was that most recent studies on the subject in developing nations 
have used Johansen's Co-integration techniques, but the strict unit-root assumption that these methodologies rely upon is often not easy to justify on economic or theoretical grounds (Hjalmarsson \& Osterholm, 2007). The estimates were done using the SPSS Version 20, and MS Excel 2010.

\section{Data Analysis and Results}

Nine economic variables were considered for the study, but three were found to have weak influences and as a result were eliminated from the equations through PAC. The analyses produced four layered regression estimates through Structural Equation Modelling (SEM), but we report on one in this study. Using the Shapiro-Wilk test as the numerical means of assessing normality, the data for these variables (apart from INFLATION) were normalised. After the standardisation of these variables using Box-Cox process. (Li, 2005; Osborne, 2010), Table 4.1 shows results of test of normality for non-normal variables. Table 4.1 now indicates that the data are normally distributed, because the Shapiro-Wilk test values show significance values which are greater than 0.05 .

Table 4.1Tests of Normality (Standardized Variables)

\begin{tabular}{|c|c|c|c|c|c|c|}
\hline \multirow{2}{*}{} & \multicolumn{3}{|c|}{ Kolmogorov-Smirnov $^{\mathrm{a}}$} & \multicolumn{3}{c|}{ Shapiro-Wilk $^{*}$} \\
\cline { 2 - 7 } & Statistic & Df & Sig. & Statistic & df & Sig. \\
\hline DFI & .189 & 84 & .212 & .567 & 84 & .087 \\
\hline TVST & .787 & 84 & .543 & .145 & 84 & .432 \\
\hline STTO & .345 & 84 & .213 & .593 & 84 & .222 \\
\hline T-BILLS & .321 & 84 & .565 & .860 & 84 & .231 \\
\hline GDP growth & .549 & 84 & .234 & .605 & 84 & .465 \\
\hline MKT & .555 & 84 & .216 & .630 & 84 & .144 \\
\hline FDI & .655 & 84 & .444 & .868 & 84 & .564 \\
\hline GFI & .366 & 84 & .409 & .544 & 84 & .099 \\
\hline
\end{tabular}

Lilliefors Significance Correction

Source: Computed Results, 2013, Using SPSS

Version 20

Another important assumption that was met prior to using the economic variables in the regression is stationarity of the variables ((Wooldrige, 2006; Granger, 1966; Nielsen, 2005; and Pierse, 1994). Tsay (1984) proposed various ways of making time series data stationery in econometric analysis. Among all the proposed methods, the most suitable and simplest is to compute the natural log of all non-stationary variables, after which Durbin-Watson's statistics can be used to verify stationarity of modified data (Nielsen, 2005). 
Table 4.2 shows Durbin-Watson statistics after converting data into stationarity data (Nielsen, 2005). Note that DFI, Capital market liquidity proxied by total value of stock traded ratio (TVST), and stock turnover ratio (STTO) are not in these tables because they have been identified and consequently removed as insignificant predictors through PCA which shall soon be seen. Durbin-Watson statistic now reveals the presence of stationarity in data because the Durbin-Watson statistics value in Table 4.2 is close to 2.

Table 4.2 Durbin-Watson Statistics after Eliminating Non-Stationarity

\begin{tabular}{|c|c|c|c|}
\hline Regression layer & Outcome Variable & Predictors & Durbin-Watson \\
\hline & MKT & GDP growth, FDI, GFI, T-BILLS, INFLATION & 2.01 \\
\hline
\end{tabular}

Source: Computed Results, 2013, Using SPSS Version 20

Another way to identify stationarity is by using a plot of Studentized Residuals (on the vertical axis) and Unstandardized Predicted values (on the horizontal axis) of regression of GDP growth and all valid predictors. Figure 4.1 shows this graph.

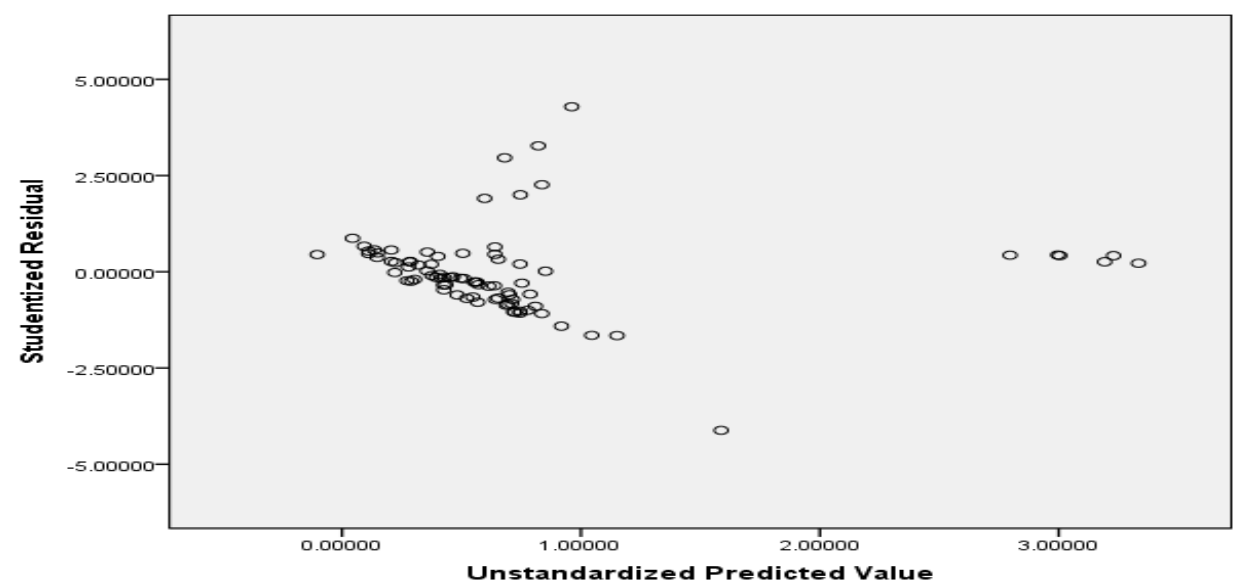

Figure 4.1 Stationary Plot for Natural Log Data

Source: Computed Results, 2013, Using SPSS Version 20

Based on Figure 4.1, it can be said that the data is stationary because no point is found to go beyond 5 and below -5 on the Studentized Residual axis. Homoscedasticity is another important assumption to be met in regression (Faraway, 2002; Scheiner, Mitchell, \& Callaban, 2002). With Figure 4.1 it can also be said that homoscedasticity assumption is met.

Correlation between dependent and criterion variable(s) is a precursor of regression. Table 4.3 shows the Pearson's correlation matrix among the variables under consideration. 
Table 4.3 Pearson's Correlations

\begin{tabular}{|c|c|c|c|c|c|c|c|}
\hline & & $\begin{array}{l}\text { GDP } \\
\text { growth }\end{array}$ & MKT & INFLATION & $\begin{array}{c}\text { T- } \\
\text { BILLS }\end{array}$ & FDI & GFI \\
\hline \multirow{3}{*}{ GDP growth } & $\begin{array}{c}\text { Pearson } \\
\text { Correlation }\end{array}$ & 1.000 & $.745^{* *}$ & 0.188 & -0.128 & $.557^{* *}$ & $.632^{* *}$ \\
\hline & $\begin{array}{c}\text { Sig. (2- } \\
\text { tailed) }\end{array}$ & & 0.000 & 0.087 & 0.247 & 0.000 & 0.000 \\
\hline & $\mathrm{N}$ & 84.000 & 84.000 & 84.000 & 84.000 & 84.000 & 84.000 \\
\hline \multirow{3}{*}{ MKT } & $\begin{array}{c}\text { Pearson } \\
\text { Correlation }\end{array}$ & $.745^{* *}$ & 1.000 & 0.071 & $-.281^{* *}$ & $.511^{* *}$ & $.707^{* *}$ \\
\hline & $\begin{array}{l}\text { Sig. (2- } \\
\text { tailed) }\end{array}$ & 0.000 & & 0.524 & 0.010 & 0.000 & 0.000 \\
\hline & $\mathrm{N}$ & 84.000 & 84.000 & 84.000 & 84.000 & 84.000 & 84.000 \\
\hline \multirow{3}{*}{ INFLATION } & $\begin{array}{c}\text { Pearson } \\
\text { Correlation }\end{array}$ & 0.188 & 0.071 & 1.000 & $.647^{* *}$ & $.231^{*}$ & 0.206 \\
\hline & $\begin{array}{l}\text { Sig. (2- } \\
\text { tailed) }\end{array}$ & 0.087 & 0.524 & & 0.000 & 0.034 & 0.060 \\
\hline & $\mathrm{N}$ & 84.000 & 84.000 & 84.000 & 84.000 & 84.000 & 84.000 \\
\hline \multirow{3}{*}{ T-BILLS } & $\begin{array}{c}\text { Pearson } \\
\text { Correlation }\end{array}$ & -0.128 & $-.281^{* *}$ & $.647^{* *}$ & 1.000 & 0.055 & -0.148 \\
\hline & $\begin{array}{c}\text { Sig. (2- } \\
\text { tailed) }\end{array}$ & 0.247 & 0.010 & 0.000 & & 0.617 & 0.180 \\
\hline & $\mathrm{N}$ & 84.000 & 84.000 & 84.000 & 84.000 & 84.000 & 84.000 \\
\hline \multirow{3}{*}{ FDI } & $\begin{array}{c}\text { Pearson } \\
\text { Correlation }\end{array}$ & 0.557 & $.511^{* *}$ & $.231^{*}$ & 0.055 & 1.000 & $.422^{* *}$ \\
\hline & $\begin{array}{c}\text { Sig. (2- } \\
\text { tailed) }\end{array}$ & 0.000 & 0.000 & 0.034 & 0.617 & & 0.000 \\
\hline & $\mathrm{N}$ & 84.000 & 84.000 & 84.000 & 84.000 & 84.000 & 84.000 \\
\hline \multirow{3}{*}{ GFI } & $\begin{array}{c}\text { Pearson } \\
\text { Correlation }\end{array}$ & $.632^{* *}$ & $.707^{* *}$ & 0.206 & -0.148 & $.422^{* *}$ & 1.000 \\
\hline & $\begin{array}{c}\text { Sig. (2- } \\
\text { tailed) }\end{array}$ & 0.000 & 0.000 & 0.060 & 0.180 & 0.000 & \\
\hline & $\mathrm{N}$ & 84.000 & 84.000 & 84.000 & 84.000 & 84.000 & 84.000 \\
\hline
\end{tabular}

Source: Computed Results, 2013, Using SPSS Version 20

Evidently, GDP growth is highly positively related to MKT, $r(82)=0.745, .000$; MKT is highly positively related to FDI, $\mathrm{r}(82)=0.511, \mathrm{p}=.000$; and GFI, $\mathrm{r}(82)=0.707, \mathrm{p}=.000$. This means it is likely that MKT is positively influenced by, GDP growth, FDI and GFI in the regression analysis.

Having tested for and met most of the assumptions of regression, Table 4.4 comes with the correlation matrix for all variables in using Principal Component Analysis (PCA) to eliminate predictors coming with weak influence (Lleras, 2002; Faraway, 2002). It can be seen that pairs such as DFI*MKT $(r=.444)$, DFI*FDI $(r=.362)$, DFI*GFI $(r=.370)$, TBILLS*INFLATION $(\mathrm{r}=.647)$, FDI*MKT $(\mathrm{r}=.511)$ and others are much correlated. The substantial number of significant correlations indicates that 
Principal Component Analysis is possible for the participating variables (factors).

Table 4.4 Correlation Matrix (1st Iteration of PCA)

\begin{tabular}{|c|c|c|c|c|c|c|c|c|c|}
\hline & & DFI & TVST & STTO & INFLATION & $\begin{array}{c}\text { T- } \\
\text { BILLS }\end{array}$ & MKT & FDI & GFI \\
\hline \multirow{5}{*}{ Correlation } & DFI & 1.000 & -.217 & .072 & .054 & -.082 & .444 & .362 & .370 \\
\cline { 2 - 10 } & TVST & -.217 & 1.000 & .026 & -.148 & .009 & -.430 & -.281 & -.328 \\
\cline { 2 - 10 } & STTO & .072 & .026 & 1.000 & -.328 & -.287 & .010 & -.130 & -.092 \\
\cline { 2 - 11 } & INFLATION & .054 & -.148 & -.328 & 1.000 & .647 & .071 & .231 & .206 \\
\cline { 2 - 10 } & T-BILLS & -.082 & .009 & -.287 & .647 & 1.000 & -.281 & .055 & -.148 \\
\cline { 2 - 10 } & MKT & .444 & -.430 & .010 & .071 & -.281 & 1.000 & .511 & .707 \\
\cline { 2 - 10 } & FDI & .362 & -.281 & -.130 & .231 & .055 & .511 & 1.000 & .422 \\
\cline { 2 - 9 } & GFI & .370 & -.328 & -.092 & .206 & -.148 & .707 & .422 & 1.000 \\
\hline
\end{tabular}

Source: Computed Result, 2013, Using SPSS Version 20

A stronger indicator of the applicability of PCA is the Keiser-MeyerOlkin (KMO) Measure of Sampling Adequacy and Bartlett's Test of Spericity. Table 4.5 is associated with the KMO and Bartlett's Test. Primarily, when the Keiser-Meyer-Olkin Measure of Sampling Adequacy is 0.50 or more, PCA can be pursued, and this is coupled with the need for Bartlett's Test of Spericity to be between .000 and 0.04 in terms of significance (i.e. Sig.), when using 0.05 level of significance. From Table 4.5, it can be agreed with that PCA can be carried out since both conditions are met.

Table 4.5 KMO and Bartlett's Test (1st Iteration)

\begin{tabular}{|l|c|c|}
\hline \multicolumn{2}{|c|}{ Kaiser-Meyer-Olkin Measure of Sampling Adequacy. } & .696 \\
\hline \multirow{3}{*}{ Bartlett's Test of Sphericity } & Approx. Chi-Square & 200.025 \\
\cline { 2 - 3 } & Df & 28 \\
\cline { 2 - 3 } & Sig. & .000 \\
\hline
\end{tabular}

Source: Computed Results, 2013, Using SPSS Version 20

Table 4.6 displays communalities for the first iteration of the Principal Component Analysis. It can be seen that Extraction values for DFI, TVST and STTO are less than 0.50 ; hence they need to be eliminated out of the PCA. 
Table 4.6 Communalities (1st Iteration PCA)

\begin{tabular}{|l|l|l|}
\hline & Initial & Extraction \\
\hline DFI & 1.000 & .408 \\
\hline TVST & 1.000 & .342 \\
\hline STTO & 1.000 & .373 \\
\hline INFLATION & 1.000 & .772 \\
\hline T-BILLS & 1.000 & .774 \\
\hline MKT & 1.000 & .802 \\
\hline FDI & 1.000 & .532 \\
\hline GFI & 1.000 & .662 \\
\hline
\end{tabular}

Extraction Method: Principal Component Analysis

Source: Computed Result, 2013, Using SPSS Version 20

Table 4.7 shows Keiser-Meyer-Olkin (KMO) Measure of Sampling Adequacy and Bartlett's Test of Spericity for the second iteration of the PCA. At this level also, the PCA can be carried out since both statistics associated with Keiser-Meyer-Olkin (KMO) Measure of Sampling Adequacy and Bartlett's Test of Spericity are satisfactory.

Table 4.7 KMO and Bartlett's Test (2nd Iteration of PCA)

\begin{tabular}{|c|c|c|}
\hline \multicolumn{2}{|c|}{ Kaiser-Meyer-Olkin Measure of Sampling Adequacy. } & .583 \\
\hline \multirow{3}{*}{ Bartlett's Test of Sphericity } & Approx. Chi-Square & 151.239 \\
\cline { 2 - 3 } & Df & 10 \\
\cline { 2 - 3 } & Sig. & .000 \\
\hline
\end{tabular}

Source: Computed Result, 2013, Using SPSS Version 20

Table 4.8 shows communalities for the second iteration of PCA. At this level, there is no factor that has an Extraction value below 0.50. This indicates that the remaining variables, INFLATION, T-BILLS, MKT, FDI and GFI are significant for analysis.

Table 4.8 Communalities (2nd Iteration of PCA)

\begin{tabular}{|c|c|c|}
\hline & Initial & Extraction \\
\hline INFLATION & 1.000 & .840 \\
\hline T-BILLS & 1.000 & .872 \\
\hline MKT & 1.000 & .836 \\
\hline FDI & 1.000 & .579 \\
\hline GFI & 1.000 & .748 \\
\hline
\end{tabular}

Extraction Method: Principal Component Analysis

Source: Computer Print, 2013, Using SPSS Version 20 
In Table 4.9 we show the regression coefficients, t-values, standard errors, and vector inflation factors of the estimated values where MKT served as a dependent variable, and FDI, GFI, T-Bills, Inflation, and GDP growth served as independent variables or predictors. In the model GFI, TBILLS, and GDP growth are the valid predictors. Their respective t-values are 4.161, -2.064 and 4.615. FDI and INFLATION were insignificant with 1.745 and $0.094 \mathrm{t}$-values respectively, though they satisfied their respective signs in the specified model. As a result, they may be ignored in the linear relationship.

Table 4.9 Coefficients ${ }^{\mathrm{a}}$ (MKT as Outcome Variable)

\begin{tabular}{|c|c|c|c|c|c|c|c|c|c|}
\hline \multirow[t]{2}{*}{ Model } & \multicolumn{2}{|c|}{$\begin{array}{l}\text { Unstandardized } \\
\text { Coefficients }\end{array}$} & \multirow{2}{*}{$\begin{array}{c}\begin{array}{c}\text { Standardized } \\
\text { Coefficients }\end{array} \\
\text { Beta }\end{array}$} & \multirow[t]{2}{*}{$\mathrm{t}$} & \multirow[t]{2}{*}{ Sig. } & \multicolumn{2}{|c|}{$\begin{array}{c}95 \% \\
\text { Confidence } \\
\text { Interval for B }\end{array}$} & \multicolumn{2}{|c|}{$\begin{array}{l}\text { Collinearity } \\
\text { Statistics }\end{array}$} \\
\hline & B & $\begin{array}{l}\text { Std. } \\
\text { Error }\end{array}$ & & & & $\begin{array}{l}\text { Lower } \\
\text { Bound }\end{array}$ & $\begin{array}{l}\text { Upper } \\
\text { Bound }\end{array}$ & Tolerance & VIF \\
\hline (Constant) & .697 & .112 & & 6.248 & .000 & .475 & .919 & & \\
\hline FDI & .089 & .051 & .136 & 1.745 & .085 & -.013 & .191 & .662 & 1.510 \\
\hline GFI & .238 & .057 & .354 & 4.161 & .000 & .124. & .352 & .554 & 1.804 \\
\hline T-BILLS & -1.172 & .568 & -.188 & $\begin{array}{c}- \\
2.064\end{array}$ & .042 & -2.302 & -.042 & .486 & 2.056 \\
\hline INFLATION & .050 & .531 & .009 & .094 & .926 & -1.008 & 1.108 & .477 & 2.095 \\
\hline GDP growth & .319 & .069 & .420 & 4.615 & .000 & .181 & .457 & .485 & 2.061 \\
\hline
\end{tabular}

a. Dependent Variable: MKT

From Table 4.9 we explain that a unit change in GDP growth contributes 0.32 to the conditional mean of MKT at a rate of between 0.18 and 0.46 (using 95\% confidence interval) when all other predictors are held constant. This is supported by Acquah-Sam \& Salami (2014); Goldsmith (1969), Shaw (1973), Garcia \& Liu (1999), and McKinnon (1973) who found that the capital markets development has a significant and positive correlation with the level of income growth in a country. According to the demand driven hypotheses, the increase in income will create new demand for financial services. Again, a unit change in GFI will contribute 0.238 to the conditional mean of MKT at a rate of between 0.12 and .0 .35 (using 95\% confidence interval) when all other predictors are held constant. New investments in the form of buildings, roads, tractors and equipment, etc, attract investments that promote capital formation and capital market development. Ngerebo-A., \& Torbira (2014) revealed the existence of positive and significant long run relationship between capital market activities and gross fixed capital formation. They suggested that growth in GFI could raise the value of listed securities, boost the value of the firms, 
increase the prices of listed equities and enlarge the size of Ghana's capital market.

Furthermore, a unit change in FDI will cause 0.089 change in the conditional mean of MKT at a rate of between -0.013 and 0.191 (using 95\% confidence interval) when all other predictors are held constant. The insignificant effect of FDI on capital market development is partly supported by the World Bank (2009; cited in World Bank Institute, 2013) which reported that in 2008 private investment flows to developing countries declined by more than 40 percent. In addition, the results show that a unit change in T-Bills contributes -1.172 to the conditional mean of MKT at a rate of between -2.302 and -.042 (using 95\% confidence interval) when all other predictors are held constant. This finding supports the work of Fama (1981) who wrote that changes in interest rates are inversely related to stocks. Finally, a unit change in inflation will cause 0.050 change in the conditional mean of MKT at a rate of between -1.008 and 1.108 (using 95\% confidence interval) when all other predictors are held constant. Macroeconomic stability, proxied by low rates of inflation, provides an incentive for firms and investors to participate in the capital market. Inflation affects capital market as it causes differences between real and nominal interest rates, and as a result changing the spending and savings of individuals, companies, and governments. Low rates of inflation is expected to have a positive impact on capital market development it encourages saving through securities purchases. The collinearity statistics at the extreme right side of Table 4.9 also indicates that there are no multicollinearity problems in the model because none of the criterion variables has its Variance Inflation Factors (VIF) to be more than 10.

Table 4.10 shows the ANOVA test for the regression of MKT from GDP growth, FDI, GFI, T-BILLS and INFLATION. The F statistic in the Table is significant at 0.05 level of significance, $F(5,78)=34.14, p=.000$. This means that MKT can linearly be predicted by GDP growth, FDI, GFI, T-BILLS, and INFLATION.

Table 4.10 ANOVA $^{\mathrm{b}}$ (MKT as Outcome Variable)

\begin{tabular}{|c|c|c|c|c|c|c|}
\hline \multicolumn{2}{|c|}{ Model } & $\begin{array}{c}\text { Sum of } \\
\text { Squares }\end{array}$ & df & Mean Square & F & Sig. \\
\hline \multirow{3}{*}{1} & Regression & 27.448 & 5 & 5.490 & 34.136 & $.000^{\text {a }}$ \\
\cline { 2 - 8 } & Residual & 12.544 & 78 & .161 & & \\
\cline { 2 - 8 } & Total & 39.991 & 83 & & & \\
\hline
\end{tabular}

a. Predictors: (Constant), GDP growth, T-BILLS, FDI, GFI, INFLATION

Table 4.11 is the model summary for the regression of MKT from GDP growth, FDI, GFI, T-BILLS and INFLATION. The Table indicates that GDP growth, FDI, GFI, T-BILLS, and INFLATION account for about 
68.6\% of the variability in MKT. The Adjusted R Square value of 66.6\% indicates further that this relationship is very strong for predictive purposes.

Table 4.11 Model Summary ${ }^{\mathrm{b}}$ (MKT as Outcome Variable)

\begin{tabular}{|c|c|c|c|c|}
\hline Model & $\mathrm{R}$ & $\mathrm{R}$ Square & Adjusted R Square & $\begin{array}{c}\text { Std. Error of the } \\
\text { Estimate }\end{array}$ \\
\hline 1 & $.828^{\mathrm{a}}$ & .686 & .666 & .40102 \\
\hline
\end{tabular}

a. Predictors: (Constant), GDP growth, T-BILLS, FDI, GFI, INFLATION

b. Dependent Variable: MKT

Source: Computed results, 2013, Using SPSS Version 20

Table 4.12 Tests of Interaction (MKT)

Dependent Variable: MKT

\begin{tabular}{|c|c|c|c|c|c|}
\hline Source & $\begin{array}{c}\text { Type III Sum of } \\
\text { Squares }\end{array}$ & Df & Mean Square & F & Sig. \\
\hline Corrected Model & $130.117^{\text {a }}$ & 104 & 1.251 & 9.683 & .000 \\
\hline Intercept & 44.579 & 1 & 44.579 & 345.000 & .000 \\
\hline Economic * SDGDP & 130.117 & 104 & 1.251 & 9.683 & .000 \\
\hline Error & 29.848 & 231 & .129 & & \\
\hline Total & 478.129 & 336 & & & \\
\hline Corrected Total & 159.966 & 335 & & & \\
\hline
\end{tabular}

$\mathrm{R}$ Squared $=.813($ Adjusted $\mathrm{R}$ Squared $=.729)$

Source: Computed Results, 2013, Using SPSS Version 20

Table 4.12, on the other hand, shows interactions tests among the independent variables in the model when MKT serves as a dependent variable and Economic (that is FDI, GFI, INFLATION and T-BILLS) as independent variable and GDP growth as covariate. The hypothesis in this case was that GDP growth did not interplay with FDI, GFI, INFLATION, and T-BILLS when MKT was being predicted by DFI, GFI, INFLATION, and T-BILLS. The test is significant at 0.05 level of significance, $F(1,104)$ $=9.683, \mathrm{p}=.000$. This means that there is a higher likelihood that GDP growth interacts with FDI, GFI, INFLATION and T-BILLS when MKT is being predicted. This reflects the initial finding that MKT is predicted by GDP growth in the fellowship of FDI, GFI, INFLATION, and T-BILLS.

\section{Summary and Conclusion}

This study investigated the macroeconomic determinates of capital market development in Ghana. It employed Structural Equation Modelling (Path Analysis) technique of analysis. Four equations were obtained from the study but we reported on one in this article. In our estimated equation GFI, T-BILLS, and GDP growth were the valid predictors of capital market 
development in Ghana. Their respective t-values were 4.161, -2.064 and 4.615. FDI and Inflation were insignificant with 1.745 and 0.094 t-values respectively. The F statistic was significant at 0.05 level of significance, $\mathrm{F}$ (5, $78)=34.14, p=.000$. This means that MKT could linearly be predicted by GDP growth, FDI, GFI, T-BILLS, and Inflation. The R Square value indicated that GDP growth, FDI, GFI, T-BILLS, and INFLATION account for about $68.6 \%$ of variability in capital market development (MKT). The Adjusted R Square value $66.6 \%$ buttressed the fact that the relationship is stronger for predictive purposes.

\section{Recommendations}

Based on the results of the study, we recommend that policy makers and regulatory bodies should formulate and implement policies that will attract investors into the capital market through products development, construction of attractive incentive packages, and improvement in access to the market so as to make investment funds available for the growth of the real sector. Also, policy-makers in Ghana must develop and implement policies that can create a favourable macroeconomic environment to cause GDP to grow so that the increased income will be spent on investment products for capital market development. Again, efforts must be made to improve the institutional capacity, regulatory framework, and the transparency of the market, and to facilitate effective dissemination of information to market participants, thereby enhancing the efficiency of Ghana's capital market. Government interest rates must be kept low so as to affect MKT development positively. Finally, there must be wide scale improvement in physical infrastructure development in Ghana to ensure that gross capital formation (GFI) will contribute positively to capital market development.

\section{References:}

Ablordeppey, D. S. (2013). Ghana still faces liquidity challenges - Terkper. Daily Graphic, Thursday, October, 2013, pg.16.

Acquah-Sam, E., \& Salami, K. (2014). Effect of capital market development on economic growth in Ghana. European Scientific Journal March 2014 edition vol.10, No.7 ISSN: 1857-7881 (Print) e - ISSN 1857- 7431

Adusei, M. (2014). Does stock market development promote economic growth in Ghana? International Journal of Economics and Finance; Vol. 6, No. 6. Retrieved from www.ccsenet.org/ijef on 20th August, 2015

Agyeman, A. C. (2010). How the Ghana stock exchange (GSE) can be improve. A Dissertation Submitted to Department of Business Administration, Ashesi University College, Ghana. Retrieved on July, 12, 2012 from http://air.ashesi.edu.gh/ 
Brasoveanu, O. L., Dragota, V., Catarama, D., \& Semenescu, A. (2008). Correlations between capital market development and economic growth: The case of Romania. Journal of Applied Quantitative Methods, Vol.3, No. 1. Retrieved on February, 2012 from http://jaqm.ro/issues/volume-3,issue1/pdfs/obreja-brasoveanu_dragota_catarama_semenescu.pdf

Carlin, W., \& Mayer, C. (2003). Finance, investment, and growth. Journal of Financial Economics, 69, 191-226.

Cohn, R. S. (2002). The development of micro-cap securities markets in subSaharan Africa: New approaches to fostering enterprise growth (in promoting growth in African capital markets). Document No. 18. Papers written following a UNITAR regional workshop on development and regulation of capital markets for Eastern and Southern Africa (Harare Zimbabwe, 19 to 23 August 2002). Retrieved on August, 2013, from http://www2.unitar.org/dfm/resource_center/document_series/document18/d ocseries18.pdf

Demirguc-Kunt, A., \& Levine. R. (1996). Stock markets, corporate finance and economic growth: An overview. The World Bank Economic Review 10 (2), pp. 223-239.

Databank (2004). Epack Investment Fund Limited Annual Report, Ghana El-Nader, M. H. \& Alraimony, D. A. (2013). The macroeconomic determinants of stock market development in Jordan. International Journal of Economics and Finance; Vol. 5, No. 6; ISSN 1916-971X E-ISSN 19169728, Canadian Centre of Science and Education Evans, L. (2010). GSE makes impact on economy. Daily Graphic, Friday, November, 12, pg 29

Faraway, J. J. (2002). Practical regression and ANOVA using R. International Journal of Applied Economics, 21 (2): 111-121.

Fama, E. (1981). Stock returns, real activity, inflation and money. American Economic Review, 71, 545-564. 0119

Garcia, F. V. and Liu, L. (1999). Macroeconomic determinants of stock market Development. Journal of Applied Economics, Vol. II. No.1

Granger, C. (1966). The typical spectral shape of an economic variable.

Econometrica, 34, 150-161

GSE (2013). Ghana alternative market (GAX). Retrieved on $26^{\text {th }}$ November, 2015 from http://www.gse.com.gh/index1.php?linkid=46

GSE (2015). Ghana fixed income market manual. Retrieved on $26^{\text {th }}$ November, $2015 \quad$ from http://www.gse.com.gh/privatecontent/File/2015/GFIM\%20Manual\%20May \%202015\%20Final.pdf

GSE Performance Review of 2013. http://www.gse.com.gh/index1.php?linkid=21\&adate=16\%2F01\%2F2014\&a rchiveid=1337\&page $=1$ 
Kaberuka, D. (2013). Sustaining Africa's economic growth: The challenges of inclusion and financing infrastructure. AACB Symposium on Financial inclusion in Africa: The challenges of financial innovations for monetary policy and the stability of financial system. Balaclava, Mauritius 22 August 2013, African Development Bank Group. Retrieved on September, 2013, from http://www.afdb.org/fileadmin/uploads/afdb/Documents

Kemboi, K. J., \& Tarus, K. D. (2012). Macroeconomic determinants of stock market development in emerging markets: Evidence from Kenya. Research Journal of Finance and Accounting, ISSN 2222-1697 (Paper) ISSN 22222847 (Online), Vol 3, No 5, www.iiste.org. Retrieved on $8^{\text {th }}$ December, 2015.

Levine, R., (1997). Financial development and economic growth: Views and agenda. Journal of Economic Literature, Vol. XXXV. pp 688-726. Retrieved on August 2012, from http://www.iset.ge/old/upload/Financial\%20development\%20and\%20econo mic\%20growth.pdf Levine, R. (2005). Finance and growth: Theory and evidence. NBER Working Paper No. 10766. Retrieved on September, 2013, from http://www.nber.org/papers/w10766

Lleras, C. (2002). Path Analysis: A Theoretical Approach to Depicting Causality. Journal of Economic Letters, 8 (2): 351-373.

McKinnon, R. I. (1973). Money and capital in economic development. Washington, DC: The Brooking Institution.

Mensah, M., Awunyo-Vitor, D., \& Sey, E. (2012). Challenges and prospects of the Ghana stock exchange. Developing Country Studies, www.iiste.org.ISSN 2224-607X (Paper) ISSN 2225-0565 (Online), Vol 2, No.10.

Nacuer, S. B., Ghazouani, S., and Omran, M (2007). The determinants of stock market development in the Middle-Eastern and North African Region. Managerial Finance, Vol. 33, (7): 477-489.

Ngerebo-A, T. A., \& Torbira, L. L. (2014). The role of capital market operations in capital formation. Journal of Finance and Investment Analysis, vol. 3, no.1, 2014, 21-33 ISSN: 2241-0998 (print version), 22410996(online). Scienpress Ltd, 2014 Retrieved on 12/12/2015 from http://www.scienpress.com/Upload/JFIA/Vol\%203_1_3.pdf

Nielsen, H. B., (2005). Non stationary time series: Conintegration and spurious regression, Statistical Theory of Econometrics, Fall, pp. 4-22.

Odife, O. D. (2002). Implementing the new partnership for African development (NEPAD): By promoting the development of the SMEs sector in the context of capital markets in Africa (In Promoting Growth In African Capital Markets). Document No. 18. Papers written following a UNITAR Regional Workshop on Development and Regulation of Capital Markets for 
Eastern and Southern Africa (Harare - Zimbabwe, 19 to 23 August 2002). Retrieved on August, 2013, from

Osamwonyi, O. I. \& Kasimu, A. (2013). Stock market and economic growth in Ghana, Kenya, and Nigeria. International Journal of Financial Research, Vol. 4, No. 2. Retrieved from www.sciedu.ca/ijfr on 20th August, 2015

Osei, V. (2004). Does the stock market matter in Ghana? A grangercausality analysis. Bank of Ghana Working Paper WP/BOG-2005/13. Retrieved from http://www.bog.gov.gh/privatecontent/Publications/Staff_Working_Papers/2 005/wp-13.pdf on 20th August, 2015.

Owusu, L. E. \& Odhiambo, M. N. (2014). Stock market development and economic growth in Ghana: an ARDL-bounds testing approach. Applied Economics Letters, Vol.21, No. 4,229-234. Retrieved from http://dx.doi.org/10.1080/13504851.2013.844315 on 20th August, 2015

Pierse, R. G. (1994). Nonstationary, unit roots and cointegartion, spurious regression. Journal of Mathematics and Social Sciences, 6 (1): 89-102.

Quaidoo, C. (2011). Stock market capitalization and economic growth in Ghana. A master's thesis, University of Cape Coast, Cape Coast. Retrieved on July 2012, from

Quartey, P., \& Gaddah, M. (2007). Long run determinants of stock market development in Ghana. Journal of African Business, Volume 8 Issue 2, pages $105-125$.

Scheiner, S. M., Mitchell, R. J., Callahan, H. S. (2002). Using path analysis to measure natural selection. Journal of Evolutional Biology, 13 (3): 423433. Senbet, L. \& Otchere, I. (2008). African stock markets. African finance for the $21^{\text {st }}$ century high-level seminar organized by the IMF Institute in collaboration with the Joint Africa Institute Tunis, Tunisia, March 4 -5, 2008. Retrieved on September, 2013, from http://www.rhsmith.umd.edu/faculty/lsenbet/lemmas\%20papers/Afican\%20S tock\%20Markets.pdf

Tsay, R. S. (1984). Order selection in stationary autoregressive models. Annals of Statistics, 12, 1425-1433.

UNITAR/DFM (2005). Online course on capital market development and regulation (advance course). Capital market development training and capacity building programmes in debt and financial management.. United Nation Training Institute

UNITAR/DFM (2005). Online course on fundamentals of capital market development and regulation. Capital market development training and capacity building programmes in debt and financial management.. United Nation Training Institute 
World Bank Institute (2013). Policies for growth: structural and sectoral policy. E-Learning course. Retrieved on August, 2013, from http://worldbank.mrooms.net/file.php/484/html/module_02_1.html

Yartey, C. A. (2008). Determinants of stock market development in emerging economies: Is South Africa different? IMF working PaperWP/08/32 Washington, International Monetary Fund. 